\title{
EKSTRAKSI BUAH PARIJOTO (MEDINILLA SPECIOSA BLUME) BERBANTU ULTRASONIK PADA BERBAGAI SUHU, WAKTU DAN KONSENTRASI PELARUT ETANOL
}

\section{Extraction of Parijoto Fruit (Medinilla speciosa Blume) by Ultrasonic Assisted Extraction at Various Times, Temperatures and Ethanol Solvent Concentrations}

\author{
Bambang Kunarto* dan Elly Yunarti Sani \\ Jurusan Teknologi Hasil Pertanian-Fakultas Teknologi Pertanian-Universitas Semarang \\ Jl Soekarno-Hatta Semarang \\ *Penulis Korespondensi, email: bbkunarto@gmail.com
}

Disubmit: 16 Februari 2020 Direvisi: 10 Maret 2020 Diterima: 18 Maret 2020

\begin{abstract}
ABSTRAK
Senyawa bioaktif dalam buah parijoto (Medinilla Speciosa Blume) berpotensi sebagai antioksidan. Agar lebih efektif dalam aplikasi buah parijoto sebagai antioksidan maka perlu dilakukan ekstraksi. Ekstraksi berbantu gelombang ultrasonik akan merusak dinding sel buah parijoto dan membebaskan kandungan senyawa yang ada didalamnya dan terjadi pemanasan lokal pada cairan sehingga meningkatkan difusi ekstrak. Tujuan penelitian ini adalah optimasi ekstraksi buah parijoto berbantu gelombang ultrasonik yang dilakukan pada berbagai lama, suhu dan konsentrasi pelarut etanol. Optimasi dilakukan dengan metoda response surface methodology (RSM). Hasil optimasi kondisi ekstraksi buah parijoto berbantu gelombang ultrasonik adalah suhu $35,30^{\circ} \mathrm{C}$, waktu 31,02 menit dan konsentrasi pelarut etanol sebesar $70,23 \%$. Pada kondisi ini diperoleh yield ekstrak 9,49 $\pm 0,05 \%$, total fenolik sebesar 0,562 $\pm 0,13 \mathrm{mg}$ GAE/g, flavonoid total $0,312 \pm 0,07 \mathrm{mg}$ CE/100g, dan aktivitas antioksidan (RSA-DPPH) 75,15 $\pm 0,41 \%$.
\end{abstract}

Kata Kunci: Antioksidan; Parijoto; Ultrasonik

\begin{abstract}
Bioactive compounds in parijoto fruit (Medinilla speciosa Blume) has potential as antioxidants. To be more effective in application of parijoto fruits as antioxidants, extraction needs to be done. Ultrasonicassisted extraction will damage the cell wall of the Parijoto fruit and free the contents of compounds contained therein and local heating occurs in the liquid, so it can increase the extract diffution. The purpose of this study is to optimize the extraction of ultrasonic-assisted extraction in parijoto fruit which is carried out at various times, temperatures and ethanol solvent concentrations. Optimization is done by the response surface methodology (RSM) method. The optimization result of extraction conditions of ultrasonic-assisted parijoto are temperature $35.30^{\circ} \mathrm{C}$, time 31.02 minutes and ethanol solvent concentration $70.23 \%$. In this condition, extract yield $9.49 \pm 0.05 \%$, phenolic total $0.562 \pm 0.13 \mathrm{mg} \mathrm{GAE} / \mathrm{g}$, flavonoid total $0.312 \pm 0.07 \mathrm{mg}$ CE/100g, and antioxidant activity (RSA-DPPH) $75.15 \pm 0.41 \%$.
\end{abstract}

Keywords: Antioxidants; Parijoto; Ultrasonic 


\section{PENDAHULUAN}

Parijoto (Medinilla speciosa Blume) adalah salah satu tanaman khas yang banyak terdapat di daerah Colo, Kudus Jawa Tengah. Tanaman parijoto tumbuh di lereng gunung dan hutan, namun dewasa ini sudah mulai dibudidayakan sebagai tanaman hias yang berkasiat (Maria et al. 2014; Wibowo et al., 2012). Penelitian yang dilakukan Wachidah (2013) menunjukkan bahwa ekstrak buah parijoto mengandung senyawa fenolik dan flavonoid yang sangat aktif sebagai antioksidan.

Senyawa bioaktif dalam buah parijoto dapat diekstrak menggunakan maserasi maupun refluk, namun menurut Feng et al. (2014) ekstraksi konvensional perlu waktu yang lama dan berakibat senyawa fenolik rusak. Kontak antara bahan dengan panas selama ekstraksi juga berakibat rusaknya senyawa bioaktif. Salah satu alternatif untuk menggantikan ekstraksi padat-cair secara konvensional adalah ekstraksi berbantu gelombang ultrasonik (ultrasonic assisted extraction/UAE). UEA adalah metode yang paling umum digunakan sebagai alternatif yang murah, sederhana, dan efisien (Mansano et al., 2019).

Salah satu manfaat metode ekstraksi UAE adalah untuk mempercepat proses ekstraksi (Kuldiloke, 2002). Dengan menggunakan ulrasonik proses ekstraksi senyawa organik pada tanaman dan bijian yang menggunakan pelarut organik dapat berlangsung lebih cepat. Ghasempou et al., 2019) menyatakan bahwa shear stress yang diberikan oleh gelombang ultrasonik menyebabkan pemecahan molekul polimer besar, sehingga menghasilkan ekstraksi senyawa fenolik yang lebih baik dibandingkan dengan metode maserasi. Hal ini dibuktikan dengan penelitian Assami et al. (2012) bahwa pre treatmant ultrasonik pada biji Carum carvi dapat meningkatkan kecepatan ekstraksi minyak atsiri (30 menit) dengan recovery 89\% dibandingan dengan perlakuan yang tidak disonikasi (90 menit). Konsentrasi senyawa alfa tokoferol dalam minyak yang terekstrak menjadi naik hampir dua kali lipat dibandingkan dengan teknik konvensional (Tyagarajan, 2012). Cameron dan Wang (2006) menyebutkan rendemen pati jagung yang didapat dari proses ultrasonik selama dua menit sebanyak 55,2-67,8\% dan hampir sama dengan rendemen yang diperoleh dari pemanasan dengan air selama 1 jam (53,5\%). Yield ekstrak biji melinjo menggunakan UAE meningkat menjadi $18,41 \pm 0,01 \%$ dibandingkan yield maserasi yang hanya $5,01 \%$ pada kondisi suhu, waktu dan pelarut yang sama (Kunarto et al., 2019). Hasil penelitian Oroian et al., (2019) menunjukkan bahwa yield ekstrak propolis dengan metoda ultrasonic lebih tinggi dibandingkabn yield eksrak menggunakan mikrowafe maupun maserasi.

Pada penelitian ini akan dilakukan optimasi ekstraksi buah parijoto berbantu gelombang ultrasonik pada berbagai lama ekstraksi, suhu ekstraksi dan konsentrasi etanol. Optimasi ekstraksi dilakukan dengan response surface methodology.

\section{METODE}

Bahan baku untuk penelitin ini adalah buah parijoto yang diperoleh dari daerah Colo, Kudus, Jawa Tengah. Bahan kimia yang digunakan antara lain: 2, 2-difenil-1-pikrillhidrazil (Sigma-Aldrich), reagent FollinsCiocalteu (Merck, Jerman), asam galat (Merck, Jerman), etanol (Merck, Jerman), katekin (Merck, Jerman), dan beberapa bahan kimia lain untuk analisis. Beberapa peralatan meliputi freeze drier (Edwards modulyo), grinder (Maksindo, Indonesia), ayakan (ASTM Standart, Indonesia), timbangan analitik (Ohaus, USA), sonicator bath (Branson 3800, Mexico), spektrofotometer UV-Vis (Shimadzu, Japan), rotary vacuum evaporator (IKA RV-10).

Buah parijoto disortasi, dicuci, dan dikeringbekukan menggunakan freeze drier selama 60 jam pada suhu $-40^{\circ} \mathrm{C}$ dan tekanan $10^{-1}$ torr. Buah parijoto kering dikecilkan ukurannya dan diayak menggunakan ayakan 30 mesh. Bubuk buah parijoto yang lolos ayakan 30 mesh disimpan pada suhu $4^{\circ} \mathrm{C}$ dalam wadah kedap udara sampai dipakai untuk perlakuan selanjutnya.

Ekstraksi buah parijoto sesuai dengan optimasi ultrasonic-asissted extraction yang dilakukan oleh Li et al. (2016) dengan modifikasi. Bubuk kering buah parijoto (20g) dimasukkan dalam gelas becker, kemudian ditambah berbagai konsentrasi pelarut etanol 1:10 (b/v). Bubuk buah parijoto tersebut diekstrak menggunakan ultrasonic bath pada frekwensi $40 \mathrm{kHz}$ dengan berbagai suhu dan waktu ekstraksi. Selanjutnya dilakukan 
filtrasi dan evaporasi sampai diperoleh ekstrak kental. Ekstrak buah parijoto kental dikeringbekukan menggunakan freeze drier 36 jam pada suhu -40 dan tekanan $10^{-1}$ torr lalu disimpan pada suhu $4^{\circ} \mathrm{C}$ dalam wadah gelap sampai dia-nalisis, yang meliputi yield ekstrak, total feno-lik, total flavonoid, dan aktivitas antioksidan (RSA-DPPH).

Desain penelitian dilakukan dengan menggunakan Response Surface Methodology (RSM). Box-Behnken Design (BBD) dipilih sebagai rancangan dengan tiga faktor yaitu suhu ekstraksi $(A=25,30,35,40$ dan 45 $\left.{ }^{\circ} \mathrm{C}\right)$, waktu ekstraksi $(\mathrm{B}=10,20,30,40,50$ menit) dan konsentrasi etanol $(C=40,50,60$, 70 dan $80 \%$ ). Nilai terbaik dari ketiga faktor dijadikan sebagai center point untuk desain RSM

Yield Ekstrak Buah Parijoto (Al-Juhaimi et al., 2016)

Persentase yield ekstrak dinyatakan sebagai berat ekstrak kering per berat sampel kering) $\times 100$.

Total Fenolik Ekstrak Buah Prijoto (Dewanto et al., 2002)

Sejumlah $125 \mu$ l sampel ekstrak buah parijoto dilarutkan dalam $500 \mu \mathrm{l}$ destilled water dan $125 \mu \mathrm{l}$ larutan reagen FolinCiocalteu. Campuran dikocok, lalu ditambah $1,25 \mathrm{ml} \mathrm{Na}_{2} \mathrm{CO}_{3} 7 \%$, dan destilled water sampai volume $3 \mathrm{ml}$. Pengukuran absorbansi pada $760 \mathrm{~nm}$ dilakukan setelah inkubasi di ruang gelap selama 90 menit. Hasil total fenolik ekstrak buah parijoto dinyatakan sebagai mg Ekuivalen Asam Galat (GAE) per gram sampel kering.

\section{Total Flavonoid Ekstrak Buah parijoto (Bhat and Yahya, 2014)}

Ekstrak buah parijoto $(1 \mathrm{ml})$ dilarutkan dalam $4 \mathrm{ml}$ destilled water. Pada waktu ke-0 dilakukan penambahan $0,3 \mathrm{ml} \mathrm{NaNO}_{2} 5 \%$ (b/v). Campuran ini dibiarkan selama 5 menit, lalu ditambah dengan $0,3 \mathrm{ml} \mathrm{AlCl}_{3} 10 \%(\mathrm{~b} / \mathrm{v})$. Pada menit ke-6, ditambah $2 \mathrm{ml} \mathrm{NaOH} 1 \mathrm{M}$ dan destilled water hingga $10 \mathrm{ml}$. Campuran ini divortex dan dibaca absorbansinya pada panjang gelombang $(\lambda) 510 \mathrm{~nm}$ menggunakan spektrofotometer UV-Vis. Hasil flavonoid total dinyatakan sebagai mg Catechin Equivalents (CE) per $100 \mathrm{~g}$ sampel kering.

Aktivitas Antioksidan (Savić-Gajić at al., 2017).

Larutan DPPH $(1 \mathrm{ml})$ ditambahkan ke dalam 2,5 ml ekstrak buah parijoto. Setelah dikocok, campuran diinkubasi pada kondisi gelap (suhu kamar) selama 30 menit, kemudian diukur absorbansinya pada 517 nm. Penghambatan radikal DPPH (\%) dihitung menggunakan formula (Ac-As)/ Ac $x$ 100, dimana Ac dan As, masing-msing adalah absorbansi kontrol dan sampel.

\section{HASIL DAN PEMBAHASAN}

\section{Respon Ekstrak Buah Parijoto Berbantu Gelombang Ultrasonik}

Nilai terbaik dari masing-masing factor adalah suhu $35^{\circ} \mathrm{C}$, waktu 30 menit dan konsnetrasi etanol 70\%. Yield ekstrak buah parijoto berkisar antara 6,70-10,10\%. Ekstrak buah parijoto mengandung senyawa total fenolik 0,33-0,57 mg GAE/g, total flavonoid berkisar antara 0,24-0,31 mg CE/g dan RSADPPH sebesar 73,00-75,28\% (Tabel 1). Tabel 2 menunjukkan model persaman kuadrat yang merupakan hubungan antara suhu ekstraksi (A), waktu ekstraksi (B), konsentrasi pelarut etanol (C) dengan respon yield ekstrak, total fenolik, total flavonoid, dan RSA-DPPH. Semua respon menunjukkan nilai lack of fit lebih besar dari 0,05 dan nilai $\mathrm{R}^{2}$ lebih besar dari 0,75 . Hasil ini cukup baik sesuai dengan pernyataan Le Man et al. (2010), bahwa persamaan cukup baik jika nilai koefisien determinasi lebih besar dari 0,75. Sedangkan menurut Li et al. (2016) nilai lack of fit yang lebih besar dari 0,05 menunjukkan bahwa model matematika untuk semua respon adalah model yang cukup baik karena menunjukkan kesesuaian antara data semua respon dengan model 
Tabel 1. Respon ekstrak buah parijoto pada berbagai suhu, waktu dan konsentrasi etanol berdasarkan desain Box-Behnken

\begin{tabular}{|c|c|c|c|c|c|c|c|}
\hline & Faktor 1 & Faktor 2 & Faktor 3 & Respon 1 & Respon 2 & Respon 3 & Respon 4 \\
\hline Run & A:Suhu & B:Waktu & $\begin{array}{c}\text { C:Konsen- } \\
\text { trasi }\end{array}$ & Yield & Fenolik & Flavanoid & RSA-DPPH \\
\hline 1 & 30 & 20 & 70 & 7,05 & 0,33 & 0.30 & 73,55 \\
\hline 2 & 40 & 20 & 70 & 7,22 & 0,40 & 0,24 & 73,63 \\
\hline 3 & 30 & 40 & 70 & 7,41 & 0,43 & 0,25 & 73,79 \\
\hline 4 & 40 & 40 & 70 & 7,42 & 0,43 & 0,26 & 73,99 \\
\hline 5 & 40 & 30 & 60 & 6,71 & 0,43 & 0,27 & 73,98 \\
\hline 6 & 30 & 30 & 60 & 6,70 & 0,42 & 0,25 & 73,81 \\
\hline 7 & 40 & 30 & 80 & 7,80 & 0,41 & 0,25 & 73,80 \\
\hline 8 & 30 & 30 & 80 & 7,70 & 0,41 & 0,25 & 73,78 \\
\hline 9 & 35 & 20 & 60 & 6,70 & 0,40 & 0,25 & 73,03 \\
\hline 10 & 35 & 40 & 60 & 6,81 & 0,40 & 0,25 & 73,89 \\
\hline 11 & 35 & 20 & 80 & 7,02 & 0,40 & 0,24 & 73,00 \\
\hline 12 & 35 & 40 & 80 & 8,05 & 0,41 & 0,25 & 73,42 \\
\hline 13 & 35 & 30 & 70 & 9,10 & 0,55 & 0,30 & 75,16 \\
\hline 14 & 35 & 30 & 70 & 10,1 & 0,57 & 0,31 & 74,92 \\
\hline 15 & 35 & 30 & 70 & 9,17 & 0,57 & 0,31 & 75,28 \\
\hline
\end{tabular}

Tabel 2. Model persamaan kuadratik

\begin{tabular}{|c|c|c|c|c|}
\hline Respon & Persamaan Kuadratik & $\mathrm{R}^{2}$ & $\mathrm{p}$-value & Lac of fit \\
\hline Yield ekstrak & $\begin{array}{l}\text { Yield }=9,46+0.036 \mathrm{~A}+0,21 \mathrm{~B}+0,46 \mathrm{C}-0,04 \mathrm{AB}+ \\
0,022 \mathrm{AC}+0,23 \mathrm{BC}-1,05 \mathrm{~A}^{2}-1,13 \mathrm{~B}^{2}-1,18 \mathrm{C}^{2}\end{array}$ & 0,87 & 0,0014 & 0,96 \\
\hline Total fenolik & $\begin{array}{l}\text { Total fenolik }=0,56+0,010 \mathrm{~A}+0,018 \mathrm{~B}-2,5 \mathrm{E} 003 \mathrm{C}- \\
0,075 \mathrm{~A}^{2}-0,09 \mathrm{~B}^{2}-0,07 \mathrm{C}^{2}\end{array}$ & 0,88 & 0,0008 & 0,14 \\
\hline $\begin{array}{l}\text { Total } \\
\text { flavonoid }\end{array}$ & $\begin{array}{l}\text { Total flavonoid }=0,531+5,0 \mathrm{E}-003 \mathrm{~A}+6,25 \mathrm{E} 003 \mathrm{~B}- \\
3,75 \mathrm{E} 003 \mathrm{C}+0 \mathrm{AB}-5 \mathrm{E}-003 \mathrm{AC}+2,5 \mathrm{E}-003 \mathrm{BC}- \\
0,027 \mathrm{~A}^{2}-0,035 \mathrm{~B}^{2}-0,025 \mathrm{C}^{2}\end{array}$ & 0,94 & 0,0002 & 0,47 \\
\hline DPPH & $\begin{array}{l}\text { DPPH }=72,12+0,059 A+0,24 B-0,089 C+0,030 A B- \\
0,038 A C-0,11 B C-0,44 A^{2}-0,94 B^{2}-0,84 C^{2}\end{array}$ & 0,94 & 0,0002 & 0,64 \\
\hline
\end{tabular}

Keterangan : $\mathrm{A}=$ suhu ekstraksi, $\mathrm{B}=$ waktu ekstraksi, $\mathrm{C}=$ konsentrasi pelarut etanol

\section{Yield ekstrak buah parijoto}

Grafik respon permukaan untuk yield ekstrak ditunjukkan pada Gambar 1a, 1b dan 1c. Interaksi suhu dengan waktu (Gambar 1a) menunjukkan bahwa yield ekstrak tertinggi terjadi pada suhu $32-38^{\circ} \mathrm{C}$ dengan waktu ekstraksi 27-35 menit. Pada Gambar 1b (suhu dengan konsentrasi pelarut etanol) menunjukkan bahwa yield ekstrak tertinggi terdapat pada suhu $33-38^{\circ} \mathrm{C}$ dengan konsentrasi pelarut etanol $68-75 \%$. Pada Gambar 1c (konsentrasi pelarut etnol dengan waktu), nilai yield ekstrak tertinggi terdapat pada waktu 27-35 menit dengan konsentrasi pelarut etanol $68-75 \%$. Semakin meningkat suhu ekstraksi, waktu ekstraksi dan konsentrasi etanol menunjuk-kan semakin meningkat yield ekstrak yang dihasilkan. Hal ini disebabkan ka- rena kesempatan buah parijoto untuk kontak dengan pelarut etanol semakin lama sehingga waktu pelarut etanol menembus dinding sel dan menarik senyawa dalam bahan juga semakin lama. Menurut Wang et al., (2012) waktu ekstraksi yang semakin lama memungkinkan lebih banyak waktu kontak untuk gelembung kavitasi memecahkan sel sampel, sehingga meningkatkan hasil ekstrak komponen bioaktif. Namun demikian di atas suhu $35^{\circ} \mathrm{C}$, waktu 30 menit dan konsentrasi etanol 70\% menunjukkan tidak terjadi peningkatan yield ekstrak karena telah melewati titik jenuh larutan. Odabas dan Koca (2016) menyatakan bahwa waktu ekstraksi berbantu gelombang ultrasonik yang terlalu lama dapat mendegradasi komponen fenolik, sehingga akan dihasilkan yield yang lebih rendah. 


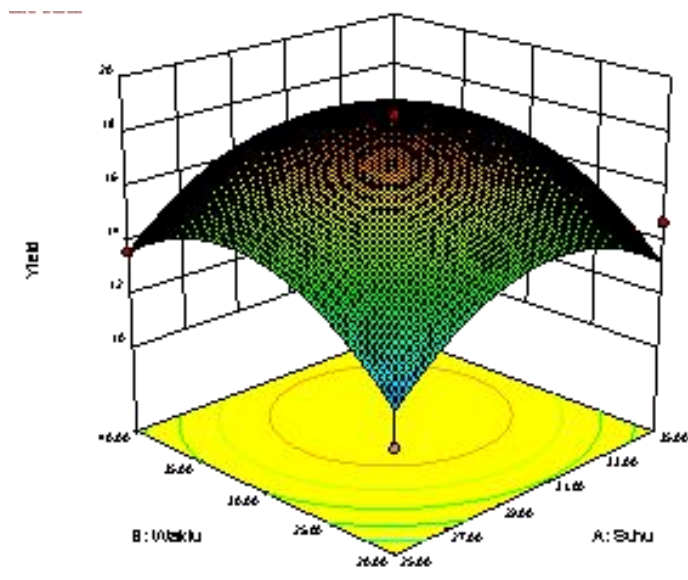

(a)

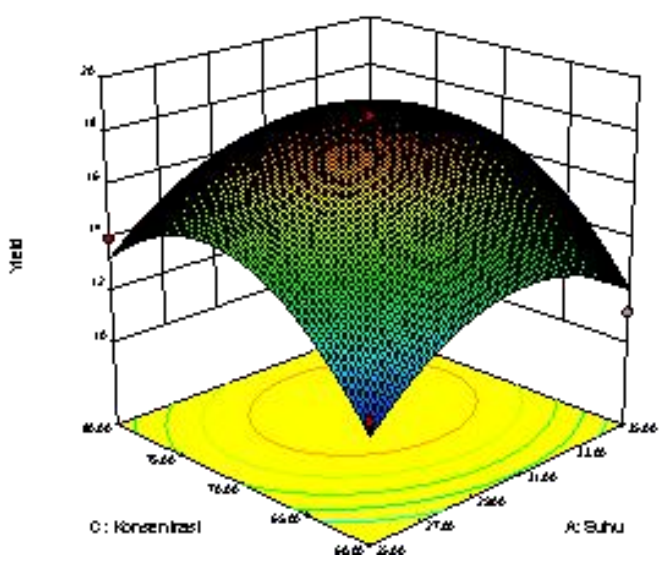

(b)

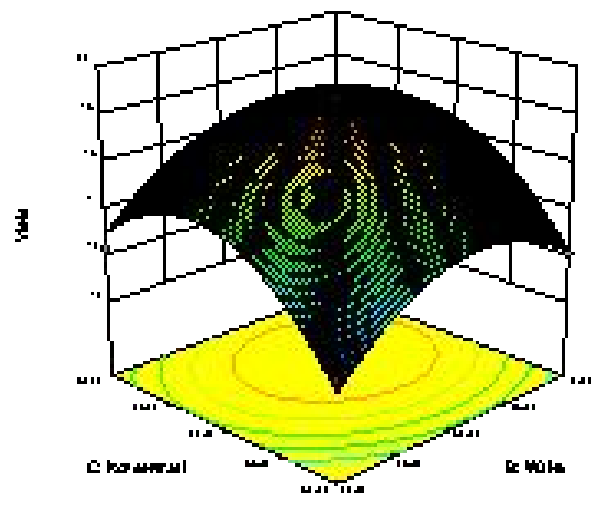

(c)

Gambar 1. Respon permukaan yield ekstrak (a) Interaksi suhu dan waktu, (b) Interaksi suhu dan konsentrasi, (c) Interaksi waktu dan konsentrasi pelarut etanol

\section{Total Fenolik Ekstrak Buah Parijoto}

Total fenolik ekstrak buah parijoto ditunjukkan pada grafik respon permukaan Gambar 2a, 2b, dan 2c. Pada Gambar 2a (interaksi suhu dan waktu) menunjukkan bahwa total fenolik tertinggi terjadi pada daerah suhu $32-38^{\circ} \mathrm{C}$ dan waktu $25-40$ menit. Gambar 2b (interaksi suhu dan konsentrasi pelarut etanol) menunjukkan bahwa total fenolik tertinggi terdapat pada suhu $32-38^{\circ} \mathrm{C}$ dan konsentrasi pelarut etanol $65-75 \%$. Pada Gambar 2c (interaksi konsentrasi dan waktu), nilai total fenolik tertinggi terdapat pada waktu 25-35 menit dan konsentrasi pelarut etanol $65-75 \%$.

Peningkatan total fenolik ekstrak buah parijoto sesuai dengan peningkatan suhu ekstraksi, lama ekstraksi dan konsentrasi pelarut etanol, namun selanjutnya terjadi penurunan total fenolik. Ekstraksi pada suhu yang tinggi akan meningkatkan kelarutan fenol. Suhu tinggi mampu melepaskan senyawa fenolik dari dinding sel (Wazir et al., 2011). Namun perpanjangan waktu ekstraksi dapat menyebabkan akumulasi senyawa yang dapat meningkatkan oksidasi (Bazykina et al. (2002). Khoddami et al., (2013) juga menyatakan bahwa komponen beberapa fenolik sensitif terhadap panas dan mudah teroksidasi. Hasil penelitian ini sejalan dengan hasil penelitian sebelumnya, yaitu ultrasound-assisted extraction pada daun perilla (Li et al., 2016), ekstraksi berbantu gelombang ulrasonik pada rice bran (Tabaraki dan Nateghi, 2011) dan bran sorghum merah (Luo et al., 2017). 


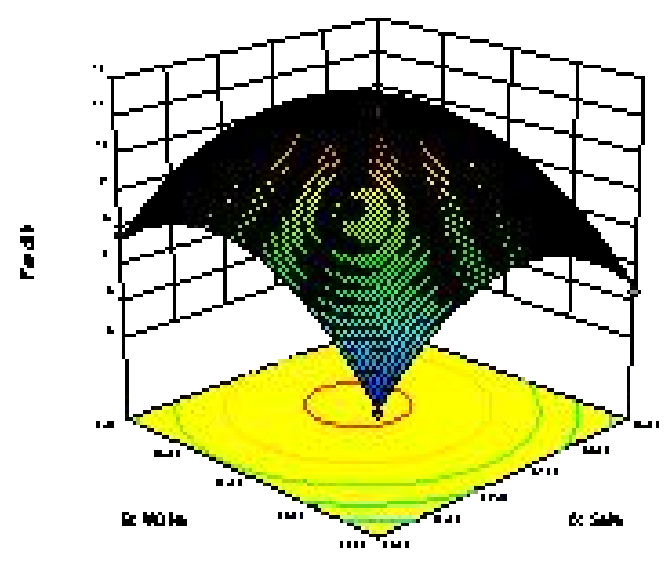

(a)

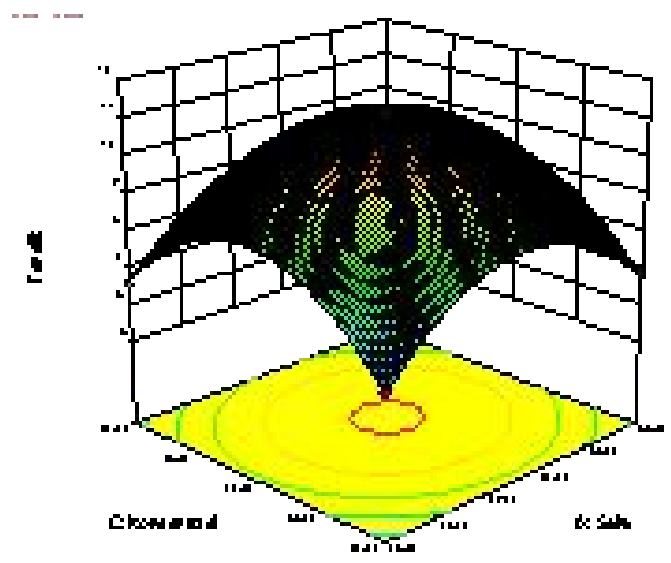

(b)

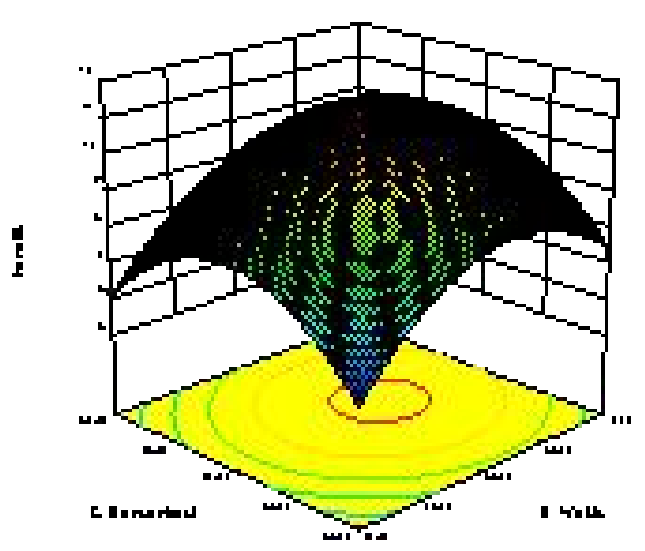

(c)

Gambar 2. Respon permukaan total fenolik. (a) Interaksi suhu dan waktu, (b) Interaksi suhu dan konsentrasi, (c) Interaksi waktu dan konsentrasi pelarut etanol

\section{Total Flavonoid Ekstrak Buah Parijoto}

Suhu ekstraksi, waktu ekstraksi dan konsentrasi pelarut etanol yang semakin meningkat akan semakin meningkatan total flavonoid. Namun setelah kondisi tertentu terjadi penurunan total flavonoid karena terjadi degradasi termal (Lu et al., 2013). Hasil ini penelitian ini mendukung peneitian sebelumnya tentang ekstraksi flavonoid dengan gelombang ultrasonik pada daun Camellia fascicularis yang menurun setelah kondisi optimum (Liu, et al., 2017). Ekstraksi Allium sativum L mengunakan UAE yang dilakukan oleh Ciric et al. (2019) juga menunjukkan pola yang sama.

Grafik total flavonoid ditunjukkan pada Gambar 3a, 3b, dan 3c. Pada Gambar 3a (interaksi suhu dan waktu) menunjukkan bahwa total flavonoid tertinggi terjadi pada daerah suhu $33-38^{\circ} \mathrm{C}$ dan waktu 25-35 menit. Gambar 3b (interaksi suhu dan konsentrasi) menunjukkan bahwa total flavonoid tertinggi terdapat pada suhu $32-38^{\circ} \mathrm{C}$ dan konsentrasi etanol 65-75\%. Pada Gambar 3c (interaksi konsentrasi dan waktu), total fla-vonoid tertinggi terdapat pada waktu 27-35 menit dan konsentrasi etanol $65-75 \%$.

\section{Aktivitas Antioksidan Ekstrak Buah Parijoto Aktivitas antioksidan ekstrak buah parijoto meningkat sesuai dengan pe- ningkatan waktu, suhu dan konsentrasi etanol, namun menurun setelah mencapai kondisi tertentu. Peningkatan aktivitas antioksidan sejalan dengan peningkatan total fenolik dan total flavonoid. Aktivitas antioksidan fenolik berkaitan erat dengan struktur yang dimiliki. Beberapa senyawa yang mempunyai efek bioaktif adalah senyawa fenol yang mem- punyai gugus hidroksi yang tersubstitusi pada posisi orto dan posisi para terhadap gugus -OH dan -OR. Senyawa fenolik dapat dijadikan sebagi indikator sifat antioksidatif pada tanaman etnoveterinari tradisional (Piluzza dan Bullitta (2011) . Hasil penelitian Terpinc et al. (2012) juga menunjukkan bahwa terdapat korelasi yang positif antara total fenolik dan aktivitas antioksidan pada biji}


Linum usitatissimum L., Brassica napus L., dan Sinapsis alba L. Peningkatan kandungan total fenolik dan total flavonoid pada ekstrak kulit orange (Citrus reticulata) juga menun-jukkan peningkatan aktivitas antioksidan yang ditandai dengan penurunan nilai $\mathrm{IC}_{50}$ (Chen et al., 2017).

Grafik respon RSA-DPPH ditunjukkan pada Gambar 4a, 4b, dan 4c. Pada Gambar 4a. Penangkapan radikal bebas DPPH tertinggi pada suhu $33-38^{\circ} \mathrm{C}$ dan waktu 25-35 menit. Gambar $4 \mathrm{~b}$ menunjukan interaksi su-hu dan konsentrasi. Nilai penangkapan radi-kal bebas DPPH tertinggi pada suhu $32-38^{\circ} \mathrm{C}$ dan konsentrasi $65-75 \%$. Pada Gambar 4c (interaksi konsentrasi dan waktu), penang-kapan radikal bebas tertinggi terdapat pada waktu 27-35 menit dan konsentrasi etanol 65-75\%.

\section{Optimasi Ekstraksi}

Hasil optimasi menunjukkan kondisi optimal ekstraksi buah parijoto berbantu gelombang ultrasonik adalah suhu $35,30^{\circ} \mathrm{C}$, waktu 31,02

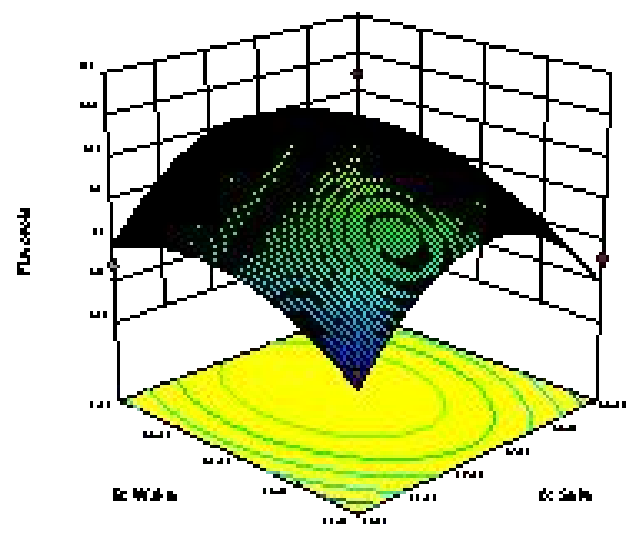

(a) menit dan konsentrasi pelarut etanol sebesar $70,23 \%$. Tabel 3 menunjukkan nilai respon prediksi dan nilai respon sebenarnya berdasarkan kondisi optimum ekstraksi. Secara berturutan nilai prediksi respon yield ekstrak $9,47 \%$, total fenolik $0,56 \mathrm{mg} \mathrm{GAE} / \mathrm{g}$, total flavonoid 0,31 mg CE/100g, dan ak-tivitas antioksidan (RSA- DPPH) 75,11\%. Desirability yang dihasilkan adalah 0,921, yang artinya dengan menggunakan suhu, waktu dan konsentrasi pelarut etanol ersebut akan menghasilkan nilai parameter/respon sebesar $92,10 \%$. Nilai respon yang sebenarnya berdasarkan kondisi optimum (Tabel 3) berturut turut adalah yield ekstrak $9,49 \pm 0,05 \%$, total fenolik $0,562 \pm 0,13 \mathrm{GAE} / \mathrm{g}$, total flavonoid $0,312 \pm 0,07 \mathrm{mg} \mathrm{CE} / 100 \mathrm{~g}$, dan penangkapan radikal bebas DPPH $75,15 \pm 0,41 \%$. Berdasarkan perhitungan diperoleh nilai residual standar error sebesar $0,05-0,6 \%$, yang menunjukkan tidak berbeda antara nilai respon yang sebenarnya dan nilai respon prediksi.

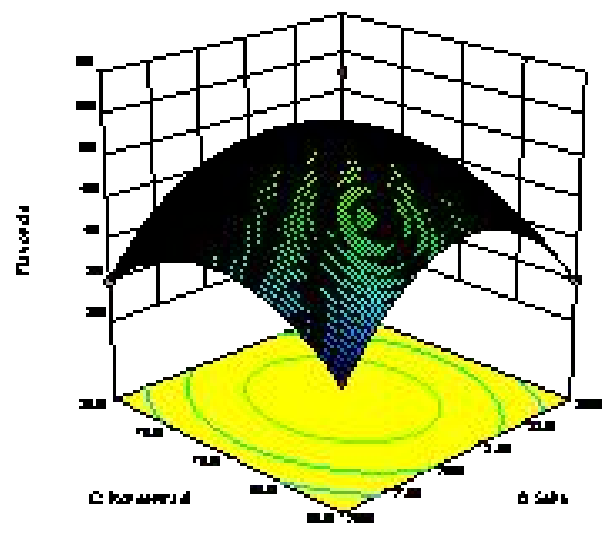

(b)

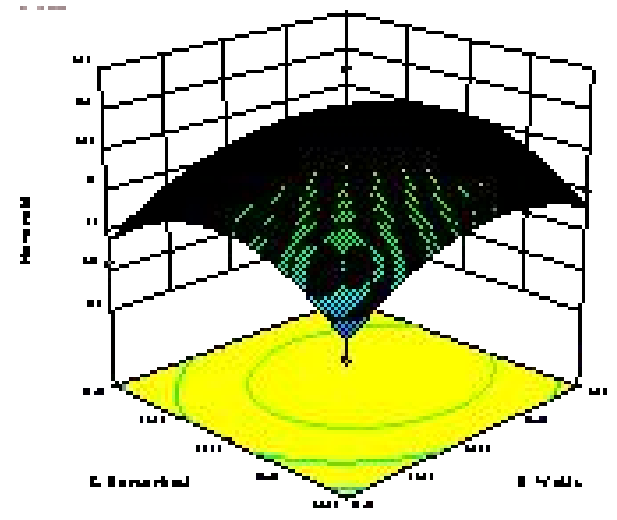

(c)

Gambar 3. Respon permukaan flavonoid total. (a) Interaksi suhu dan waktu, (b) Interaksi suhu dan konsentrasi, (c) linteraksi waktu dan konsentrasi pelarut etanol 


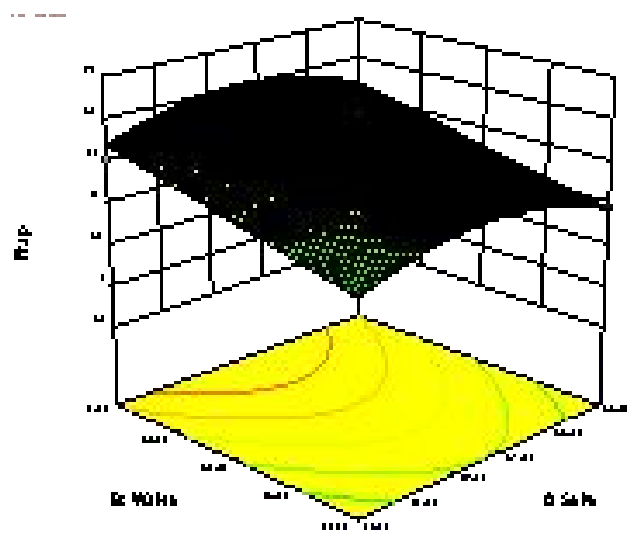

(a)

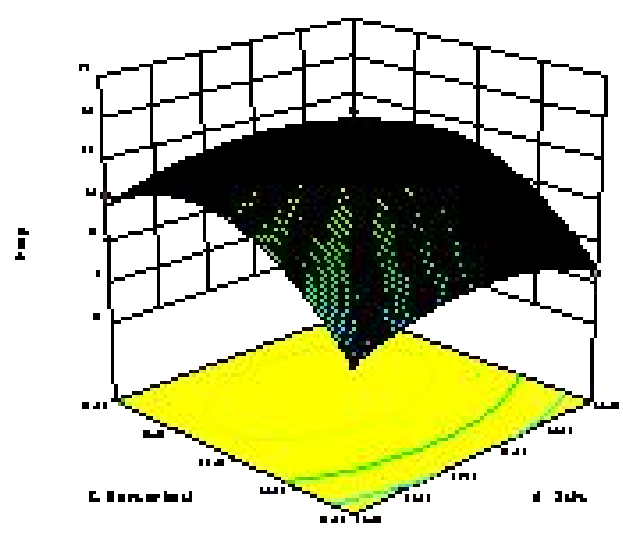

(b)

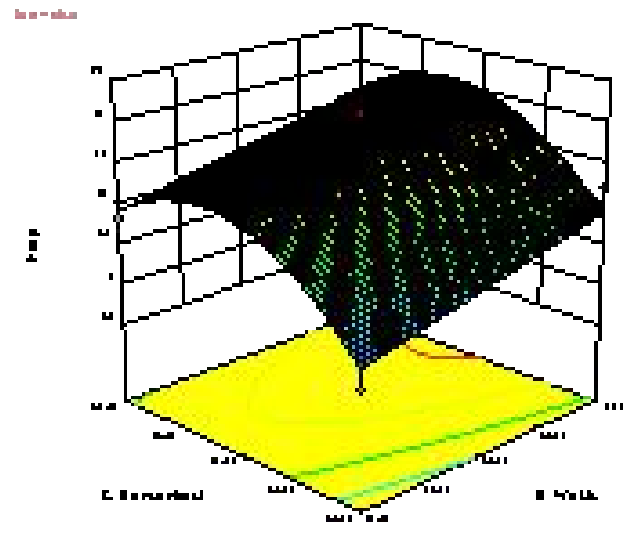

(c)

Gambar 4. Respon permukaan RSA-DPPH. (a) Interaksi suhu dan waktu, (b) Interaksi suhu dan konsentrasi, (c) Interaksi waktu dan konsentrasi pelarut etanol

Tabel 3. Nilai respon prediksi dan nilai sebenarnya

\begin{tabular}{lccc}
\hline \multicolumn{1}{c}{ Respon } & Nilai Prediksi & Nilai Sebenarnya & $\begin{array}{c}\text { Residual Standar } \\
\text { Error }(\%)\end{array}$ \\
\hline Yield ekstrak (\%) & 9,47 & $9,49 \pm 0,05$ & 0,21 \\
Total fenolik (mgGAE/g) & 0,56 & $0,562 \pm 0,13$ & 0,18 \\
Total Flavonoid (mg CE/100g) & 0,31 & $0,312 \pm 0,07$ & 0,65 \\
RSA-DPPH (\%) & 75,11 & $75,15 \pm 0,41$ & 0,05 \\
\hline
\end{tabular}

\section{SIMPULAN}

Hasil optimasi kondisi ekstraksi buah parijoto berbantu gelombang ultrasonik adalah suhu $35,30^{\circ} \mathrm{C}$, waktu 31,02 menit dan konsentrasi pelarut etanol sebesar 70,23\%.

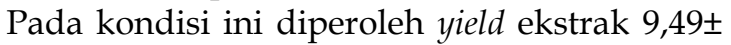
$0,05 \%$, total fenolik sebesar $0,562 \pm 0,13 \mathrm{mg}$ $\mathrm{GAE} / \mathrm{g}$, flavonoid total $0,312 \pm 0,07 \mathrm{mgCE} / 100 \mathrm{~g}$, dan aktivitas antioksidan (RSA-DPPH) 75,15 $\pm 0,41 \%$.

\section{DAFTAR PUSTAKA}

Al-Juhaimi, -F., Adiamo, -O.Q., Ghafoor, -K. and Babiker, E.E. 2016. Optimization of ultrasonic-assisted extraction of phenolic compound from fenugreek (Trigonella foenum-graecum L.) seed. CyTA-Journal of Food 14(3), 369-374. https:// doi.org/ 10.1080/19476337.2015.1110202.

Assami, -K., Pingret, -D., Chemat, -S., Mekh lati, -Y.B., Chemat, -F. 2012. Ultrasound induced intensification and selective extraction of essential oil from Carum 
carvi L. Seeds. Chemical Engineering and Processing. 62, 99-105. https://doi.org/ 10.1016/j.cep.2012.09.003

Bazykina, -N.I., Nikolaevskii, -A.N., Filippenko, -T.A, Kaloerova, -V.G. 2002. Optimization of conditions for the extraction of natural antioxidants from raw plant materials. Pharmaceutical Chemistry Journal, 36(2), 46-49. https:// doi.org/10.1023/A:1016024300843.

Bhat, -R., Yahya, -B.N. 2014. Evaluating melinjau (Gnetum gnemon L.) seed flour quality as a base for development of novel food products and food formulations. Food Chemistry. 156, 42-49. https://doi.org/ 10.1016/j.foodchem.20 14.01.063.

Chen, -X.M., Tait, -A.R., Kitts, -D.D. 2017. Flavonoid composition of orange peel and its association with antioxidant and anti-inflammatory activities. Food Chemistry, 218, 15-21. https:// doi.org/10.1016 /j.foodchem. 2016.09.016.

Ciric, -A., Krajnc, -B., Heath, -D. Ogrinc, -N. 2019. Response surface methodology and artificial neural network approach for the optimization of ultrasound-assisted extraction of polyphenols from garlic. Food and Chemical Toxicology. 135, 110 976. https://doi.org/10.1016/j.fct.2019. 110976

Dewanto, -V., Wu, -X., Adom, K-.K., Liu, -R.H. 2002. Thermal processing enhances the nutritional value of tomatoes by increasing total antioxidant activity. Journal of Agricultural and Food Chemistry 50(10), 3010-3014. https://doi.org/10.1021/j.f01 15589.

Dolatowski, -Z.J., Stadnik, -J. Stasiak, -D. 2007. Applications of ultrasound in food technology. Acta Sci. Pol. Tecnol. Aliment. 6(3), 88-99. http://www.food.actapol.net /issue3/volume/8_3_2007.pdf

Feng, -S., Luo, -Z., Tao, -B., Chen, -C. 2014. Ultrasonic-assisted extraction and purification of phenolic compounds from sugar cane (Saccaharum oficinarum L.) rinds. LWT-Food Science and Technology. 60(2), 970-976. https://doi.org/ 10.1590/1678-457x.13516

Ghasempour, -N., Rad, -A., Javanmard, -M., Azarpazhouh, -E. Armin, -M., 2019. Optimization of conditions of ultrasoun sound-assisted extraction of phenolic compounds from orange pomace
(Citrus sinensis). International Journal of Biology and Chemistry. 12(2), 10-19. https://doi.org/10.3390/antiox8080248

Koddami, -A., Wilkes, -M., Roberts, -T. 2013. Techniques for analysis of plant phenolic compounds. Molecules, 18(2), 23282375. https://doi.org/10.3390/molecul es18022328.

Kuldiloke, -J. 2002. Effect of ultrasound, temperatrure and pressure treatments onn enzyme activity and quality indicators of fruit and vegetable juices. Dissertationder Technischen Univeritat Berlin. Berlin.

Kunarto, -B., Sutardi, Supriyanto, Anwar, -C. 2019. Optimasi ekstraksi berbantu gelombang ultrasonic pada biji melinjo kerikil (Gnetum gnemon L., 'Kerikil') menggunakan reponse surface methodology. Jurnal aplikasi teknologi pangan. 8(3),104111.

Li, -H.Z., Zhang, -Z.J., Xue, -J., Cui, -L.X., Chen, -T. 2016. Optimization of ultrasound-assisted extraction of phenolic compounds, antioxidants and rosmarinic acid from perilla leaves using response surface methodology. Food Science and Technology. 36(4), 686-693. https:// doi.org/10.1590/1678-457x.13516.

Liu, -Y., Luo, -X., Lan, -Z., Tang, -J., Zhao, -P., Kan, -H. 2017. Ultrasonic-assisted extraction and antioxidant capacities of flavonoids from Camellia fascicularis leaves. CyTA-Journal of Food. 16(1), 105112. https://doi.org/10.1080/ 19476337. 2017.1343867.

Lu, -J., Zhou, -C., Rong, -O., Xu, -Y., Zhou, -B., $\mathrm{Li},-\mathrm{Z}$. 2013. Optimization of microwaveassisted extraction of flavonoids from Cryptotaenia japonica hassk using response surface methodology. Advance Journal of Food Science and Technology. 5, 310-317. https://doi.org/10.19026/ajfst. 5.3262.

Mason, -T., Lorimer, -J.P. 2002. Applied sonocchemistry: uses of power ultrasound in chemistry and processing. Wiley-VCH Verlag GmbH. Weinheim.

Maffei, -M. 2003. Dietary supplements of plat origin: a nutrition and health approach. Taylor \& Francis Ltd.

Manzano Durán, -R., Sánchez, -J.E.F., Velardo-Micharet, -B. Gómez, -M.J.R., 2019. Multivariate optimization of ultrasound-assisted extraction for the determination of phenolic compounds 
in plums (Prunus salicina Lindl.) by high-performance liquid chromatography (HPLC). Instrumentation Science $\mathcal{E}$ Technology. 48(2), 113-127. https://doi.org/10.1080/10739149.2019. 1662438

Maria, -C., Buta, -E., Hort -D. 2014. Medinilla: an exotic and attractive indoor plant with great value. Journal of Horticulture, Forestry and Biotechnology. 16(2), 9-12. https:// www.cabi.org/isc/FullTextPD F/2012/20123267534.pdf

Odabas, -H.I., Koca, -I. 2016. Application of response surface methodology for optimizing the recovery of phenolic compounds from hazelnut skin using different extraction methods. Industrial Crops and Products. 91,114-124. https:// doi.org/10.1016/j.indcrop.2016.05. 033.

Oroian, -M., Dranca, -F. Ursachi, -F., 2019. Comparative evaluation of maceration, microwave and ultrasonic-assisted extraction of phenolic compounds from propolis. Journal of Food Science and Technology. 57(1), 70-78. https://doi.org/ 10.1007/s13197-019-04031-x

Piluzza, -G., Bullitta, -S. 2011. Correlations between phenolic content and antioxidant properties in twenty-four plant species of traditional ethnoveterinary use in the Mediterranean area. Pharma ceutical Biology. 49(3), 240247. https:// doi.org/10.3109/13880209.2 010.501083

Savić-Gajić, -I., Savić, -I.M., Nikolić, -L.B., Popsavin, -M.M., Rakić, -S.J. 2017. The improvement of phtostability and antioxidant activity of trans-resveratrol by cyclodextrins. Advanced Technologies 6(2), 18-25. https://doi.org/10.5937/sav teh1702018S.

Tabaraki, -R., Nateghi, -A. 2011. Optimization of ultrasonic-assisted extraction of natural antioxidants from rice bran using response surface methodology. Ultrasonics Sonochemistry. 18(6), 1279-1286. https://doi.org/10.1016/ j.ultsonch.2011 .05 .004

Terpinc, -P., Čeh, -B., Ulrih, -N.P., Abramovič, -H. 2012. Studies of the correlation between antioxidant properties and the total phenolic content of different oil cake extracts. Industrial Crops and Products. 39, 210-217. https://doi.org/10. 1016/j.indcrop.2012.02.023

Wachidah, -L.N. 2013. Uji aktivitas antioksidan serta penentuan kandungan fenolat dan flavonoid total dari buah parijoto (Medinilla speciosa Blume). Skripsi UIN Syarif Hidayatullah Jakarta.

Wang, -X., Wu, -Q., Wu, -Y., Chen, -G., Yue, W., and Liang, Q. 2012. Response surface optimized ultrasonic-assisted extraction of flavonoids from Sparganii rhizoma and evaluation of their in vitro antioxidant activities. Molecules. 17(6), 6769-6783. https://doi.org/10.3390/mo lecules17066769.

Wibowo, -H.A., Wasino, Setyowati, -D.L. 2012. Kearifan lokal dalam menjaga lingkungan hidup (studi kasus masyarakat di Desa Colo Kecematan Dawe Kabupaten Kudus). Journal of Educational Social Studies. 1 (1), 25-30. https://journal.unnes.ac.id/sju/index.p $\mathrm{hp} /$ jess/article/view/79/71 